\title{
Modelling of consumption and assimilation in Abra alba (Mollusca, Bivalvia)
}

\author{
J. M. Amouroux ${ }^{1}$, A. Grémare ${ }^{1}$, J. Amouroux ${ }^{2}$ \\ 'Laboratoire Arago, F-66650 Banyuls/mer, France \\ ${ }^{2}$ ENSCP, 11 rue Pierre et Marie Curie, Université Paris VI, F-75005 Paris, France
}

\begin{abstract}
The deposit-feeding bivalve Abra alba was fed over 3 different periods of time $(4,10,48 \mathrm{~h})$ on 3 species of different-sized, ${ }^{14} \mathrm{C}$-labelled diatoms: Navicula incerta, Nitzschia acicularis and Nitzschia sp. Because of the complexity of the exchanges of matter between the different compartments (i.e. bivalves, $\mathrm{CO}_{2}$, dissolved organic matter, algae) of our system, the experimental study alone was insufficient to quantify the amounts of organic matter ingested, excreted or assimilated. Therefore, we developed an analog model which allowed the calculation of such information. A. alba ingested Nitzschia sp. rather than $N$. acicularis and $N$. incerta. Comparison of results in the presence and absence of $A$. alba suggests that bivalve activity affected the metabolism of sedimented diatoms: $N$. incerta seemed stimulated whereas $N$. acicularis and Nitzschia sp. were inhibited. The adaptative dark metabolism of these species is probably different for the same conditions of darkness and bioturbation.
\end{abstract}

\section{INTRODUCTION}

Organic matter available for deposit-feeders is composed of heterogeneous particles including detritus and microorganisms (Newell 1965, Fenchel 1970, Lopez et al. 1977. Nielsen \& Kofoed 1982, Reise 1983 Harvey \& Luoma 1984, Kemp 1987). Deposit-feeders selectively collect and ingest such particles (Odum 1968, Fenchel 1972, Hylleberg \& Galucci 1975, Nielsen \& Kofoed 1982, Whitlach \& Weinberg 1982, Briggs 1985, Petch 1986). It is difficult to determine whether detrital, algal, or bacterial components are ingested preferentially. Furthermore, because dissolved organic matter (DOM) and faeces may also be consumed, it is difficult to quantify the amount of ingested material derived from the sediment.

Through bioturbation and predation, deposit-feeding organisms modify the balance of the different communities of microorganisms living on the sediment. The growth of these microorganisms is often stimulated by the presence of deposit-feeders (Hargrave 1970b, Murphy 1985, Branch \& Pringle 1987). Many deposi-feeders also stimulate bacterial production via cultivation on aggregates ('gardening') (Hylleberg 1975, Reichardt 1988). Deposit-feeding organisms have developed sev- eral elaborate food-collecting systems (e.g. combs, sticky palps, external siphons). Such diversity, coupled with the effects of deposit-feeders on their food sources, complicates the design of experimental studies assessing the quantitative aspects of nutrition in depositfeeding organisms. For example, the change of algal radioactivity over time (i.e. loss of $\mathrm{DOM}$ and $\mathrm{CO}_{2}$ ) has been studied experimentally by numerous authors (e.g. Fogg 1966, Mague et al. 1980, Smith \& Horner 1981, Jensen 1983, Amouroux 1986b). Because deposit-feeders are able to absorb DOM, such losses complicate quantitative studies of nutrition in deposit-feeding organisms. Dring \& Jewson (1982) recommended the use of compartmental analysis (Grégoire 1972), coupled with an analog modelisation for such studies.

In this study we used this method to compare the consumption of 3 different live diatoms by the bivalve Abra alba. An analog model was then built to simulate the exchanges of radioactivity between the different compartments $\left(\mathrm{CO}_{2}\right.$, DOM, particulate matter, bivalves). Calculation was thus possible of the amount of organic matter actually ingested, assimilated, and excreted (in dissolved and particulate form) by the bivalves. The model also allowed distinction between faeces and non-ingested diatoms 


\section{MATERIALS AND METHODS}

Clams. Abra alba (Wood), a deposit-feeding bivalve of up to ca $12 \mathrm{~mm}$ length, is common in all lagoons along the Languedoc-Roussillon coast of France. It burrows 3 to $5 \mathrm{~cm}$ deep; from below the sediment surface, $A$. alba sucks up the thin top sediment layer by movement and numerous distortions of its 4 to $5 \mathrm{~cm}$ long siphons. The exhalant siphon draws a regular current of water into the burrow where the faeces are stored (J.M. A. pers. obs.). In other deposit-feeders, such faecal pellets may be triturated to collect the organic matter corresponding to bacterial production ('gardening'; 泣ylleberg 1975). The clams were collected at a shallow station $(<1 \mathrm{~m}$ ) of the Canet lagoon. In the laboratory they were then kept for several months in tanks provided with running natural seawater and natural muddy sediment.

Diatoms. Food sources were 3 diatoms: Navicula incerta (Grunow), Nitzschia acicularis (Wm Smith) and Nitzschia sp. (provided by Dr C. Riaux fromthe Roscoff Laboratory, France). $N$. incerta is $16 \mathrm{~mm}$ long and contains $5.9 \times 10^{-10} \mathrm{~g}$ organic matter $\left(500^{\circ} \mathrm{C}\right.$ for $\left.5 \mathrm{~h}\right)$ per cell; $N$. acicularis is $60 \mathrm{~mm}$ long and contains $1.5 \times 10^{-10} \mathrm{~g}$ organic matter per cell; Nitzschia sp. is $11 \mathrm{~mm}$ long and contains $1.1 \times 10^{-10} \mathrm{~g}$ organic matter per cell. Diatoms were grown at $18^{\circ} \mathrm{C}$ for $15 \mathrm{~d}$ under constant illumination (1700 lux) in $\mathrm{F} / 2$ medium (Guilliard \& Ryther 1962). Cultures were labelled with $\mathrm{NaH}^{14} \mathrm{CO}_{3}$ (CEA) $12 \mathrm{~h}$ before each experiment.

Dissolved substances; filtrates. Live diatoms exude much dissolved organic matter (DOM) (e.g. Fogg 1966 , Jensen 1983, Admiraal et al. 1986). After centrifugation, ${ }^{14} \mathrm{C}$-labelled diatom cultures were deep-frozen $\left(-40^{\circ} \mathrm{C}\right)$, autoclaved (to break the cell walls), and filtered on a $0.2 \mu \mathrm{m}$ filter. Filtrates containing the labelled soluble material were collected, their radioactivities measured and compared with those of filters corresponding to particulate organic matter in order to quantify the concentration of organic matter of the filtrates (Amouroux 1984). Biochemical composition of filtrates probably differs from the biochemical composition of natural exudates

Procedure. Cultures were centrifuged, resuspended in filtered seawater and their concentration adjusted so as to correspond to a total organic dry weight of $20 \mathrm{mg}$ per flask (they were not re-adjusted during experiments). Before use, bivalves were placed in filtered seawater at $15^{\circ} \mathrm{C}$ in darkness for at least $24 \mathrm{~h}$ to empty their digestive tracts; 30 bivalves of known size, corresponding to a total of $185 \mathrm{mg}$ flesh dry weight, were introduced into each flask immediately after food addition. The experimental set up consisted of a $350 \mathrm{ml}$ flask containing $300 \mathrm{ml}$ of filtered seawater. The liquid medium was mixed by gentle air bubbling sufficient for oxygenation without disturbing sedimentation of diatoms. At the outlet, air was passed through $\mathrm{NaOH}$ traps to capture the labelled respiratory $\mathrm{CO}_{2}$. For each run 3 replicates and a control without bivalves were carried out in darkness at $15^{\circ} \mathrm{C}$. Under these conditions, the bivalves fed ard apparently were not stressed (J. M. A. pers. obs.)

Nine ( 3 series of 3 replicates) 4 h experiments were carried out to assess the consumption of DOM (filtrates) by Abra alba. Experiment duration was limited to restrict bacterial activity. Three series of experiments $(4,10,24 \mathrm{~h})$ were carried out to measure consumption of Navicula incerta, Nitzschia acicularis and Nitzschia sp. by Abra alba. All experiments were conducted at $15^{\circ} \mathrm{C}$ in darkness. Bacterial acitvity was very low due to bivalve filtration.

At the end of experiments, radioactivity corresponding to the 4 compartments (the bivalves in toto, particulate organic matter [POM], DOM and $\mathrm{CO}_{2}$ ) was measured in a Beckman liquid scintillator (see Amouroux 1984 and 1986a for details). In each control, cells were resuspended after strongly shaking the flask and then counted on a microgrid. For feeding experiments (the presence of bivalves) non-ingested diatoms were not counted at the end of the experiments since they were mixed with faeces and biodeposits of Abra alba.

Modelling. Analog computation (Goldstein \& Elwood 1971) was used to establish continuity among experimental data and to quantify the exchanges between the different compartments. Such a model allowed the calculation of the amount of organic matter moved through the different compartments, and of the changes over time of the radioactivity corresponding to compartments that could not be measured experimentally (e.g. faeces). Fitting the model to our experimental set-up required several trials involving different assumptions. We present here only the best fitted model (i.e. the one which seems to correspond to the most valid hypotheses). The model was used as a tool to test different hypotheses relative to the tranfer of matter among the different compartments of the system studied. When the model provided a good description of our experimental data we concluded that our priorhypotheses (taken into account in the model) were confirmed.

System and differential equations: The system (Fig. 1) was considered to be closed. Its compartments were diatoms, bivalves, $\mathrm{CO}_{2}, \mathrm{DOM}$ and faeces. Each of these should have been analysed separately during the experimental study. However, experimental measurements of radioactivity were carried out in only 4 (bivalves, DOM, $\mathrm{CO}_{2}, \mathrm{POM}$ ) compartments. It was not possible to measure radioactivity corresponding to diatoms and faeces separately. Mass transfer dynamics of the system Bivalves-Diatoms-Seawater were rep- 


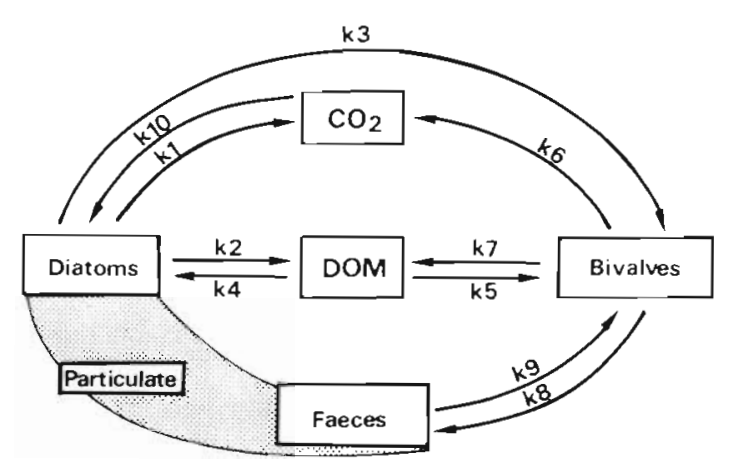

Fig. 1. Five-compartment model of 'Diatom-Bivalve' system showing exchanges studied and numbered kinetic constants of mass transfer

resented by an interaction of 'kinetic' equations reflecting the rates of exchanges between the compartments:

$$
\begin{aligned}
& \frac{\mathrm{d}(\text { Diat })}{\mathrm{dt}}=+\mathrm{k} 4(\text { Diss })+\mathrm{k} 10\left(\mathrm{CO}_{2}\right)-\mathrm{k} 1 \text { (Diat) } \\
& -\mathrm{k} 2 \text { (Diat) - k3 (Diat) } \\
& \begin{aligned}
\frac{\mathrm{d}(\text { Biv })}{\mathrm{dt}}=+ & \mathrm{k} 3(\text { Diat })+\mathrm{k} 5(\text { Diss })+\mathrm{k} 9(\text { Faec }) \\
& -\mathrm{k} 6(\text { Biv })-\mathrm{k} 7(\text { Biv })-\mathrm{k} 8(\text { Biv })
\end{aligned} \\
& \frac{d(\text { Diss })}{d t}=+k 2(\text { Diat })+k 7(\text { Biv })-k 4(\text { Diss })-k 5(\text { Diss }) \\
& \frac{d(\text { Faeces })}{d t}=+k 8(\text { Biv })-k 9(\text { Faec }) \\
& \frac{\mathrm{d}\left(\mathrm{CO}_{2}\right)}{\mathrm{dt}}=+\mathrm{k} 1(\text { Diat })+\mathrm{k} 6(\mathrm{Biv})-\mathrm{k} 10\left(\mathrm{CO}_{2}\right) \\
& \frac{d(\text { Part })}{d t}=+\frac{d(\text { Diat })}{d t}+\frac{d(\text { Faec })}{d t}
\end{aligned}
$$

where $k 1, k 2, \ldots, k 10=$ kinetic constants of mass transfer; ( ) = radioactive content of each compartment expressed as a percentage of total radioactivity initially introduced into the system; $\mathrm{t}=$ time. The computer circuit simulating these equations, together with kinetic constants, is illustrated in Fig. 2

Determination of the kinetic constants: The system Bivalve-Diatom was subdivided into 2 sub-systems (i.e. Diatom-DOM-CO $\mathrm{CO}_{2}$ and Bivalve-DOM-CO- -Faeces) to permit evaluation of the kinetic constants. The first sub-system (Fig. 3) corresponds to changes over time in the specific radioacitvity of diatoms alone (control experiments); the second subsystem corresponds to the consumption of diatoms exudates by the bivalves. Experiments with filtrates allowed for the computation of $\mathrm{k} 5$ and $\mathrm{k} 7$ which correspond to the exchanges between bivalves and DOM (Fig. 1). The study of variation over time of diatoms alone (controls) allowed for the computation of $\mathrm{k} 2$ and $\mathrm{k} 4$ which correspond to the exchanges between diatoms and DOM, and of $\mathrm{k} 1$

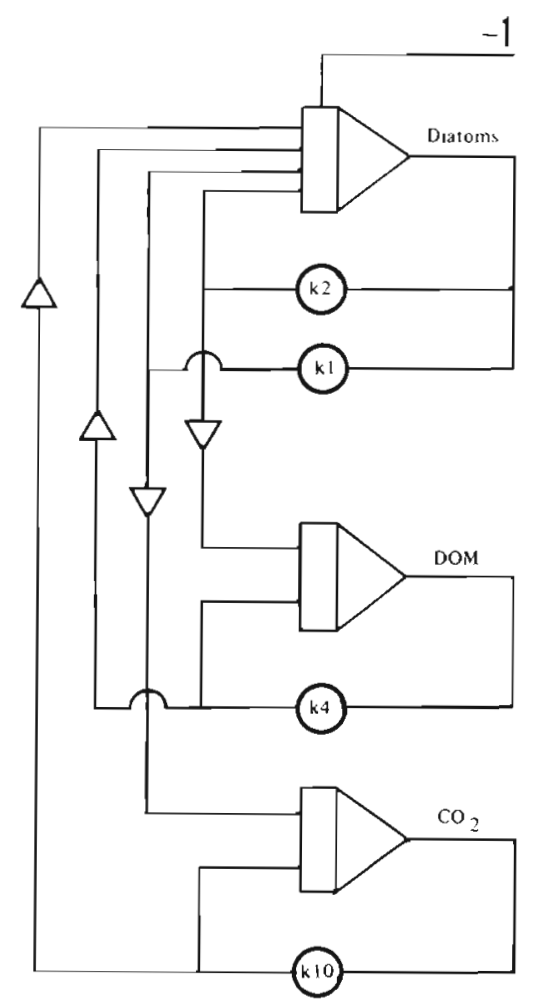

Fig. 2. Circuit diagram of computer and dispiay constants after fitting of model 'Diatom-Bivalve' system

and $\mathrm{k} 10$ which correspond to exchanges between $\mathrm{CO}_{2}$ and diatoms. These constants were introduced in the model Diatom-Bivalve-Seawater.

Calculation of the amount ingested and assimilated: The experiments alone did not allow distinction between live diatoms and those rejected in bivalves faeces. The computation of the amount of radioactivity consumed ingested (in particulate form) and assimilated by the bivalves required computation of the cumulated amounts of radioactivity within the different compartments. This could only be achieved through modelling of the system. The amount consumed was set as the total amount of radioactivity corresponding to bivalves soft parts plus excretory products (faeces, $\mathrm{DOM}, \mathrm{CO}_{2}$ ). The amount ingested was set as the difference between total consumption (see above) and DOM consumed by the bivalves. The amount assimilated was set as the difference between total consumption and faeces produced.

\section{RESULTS}

\section{Experimental study}

Control: changes in live diatoms alone over time

The concentrations of viable sedimented diatoms were constant throughout all experiments (Table 1). In 


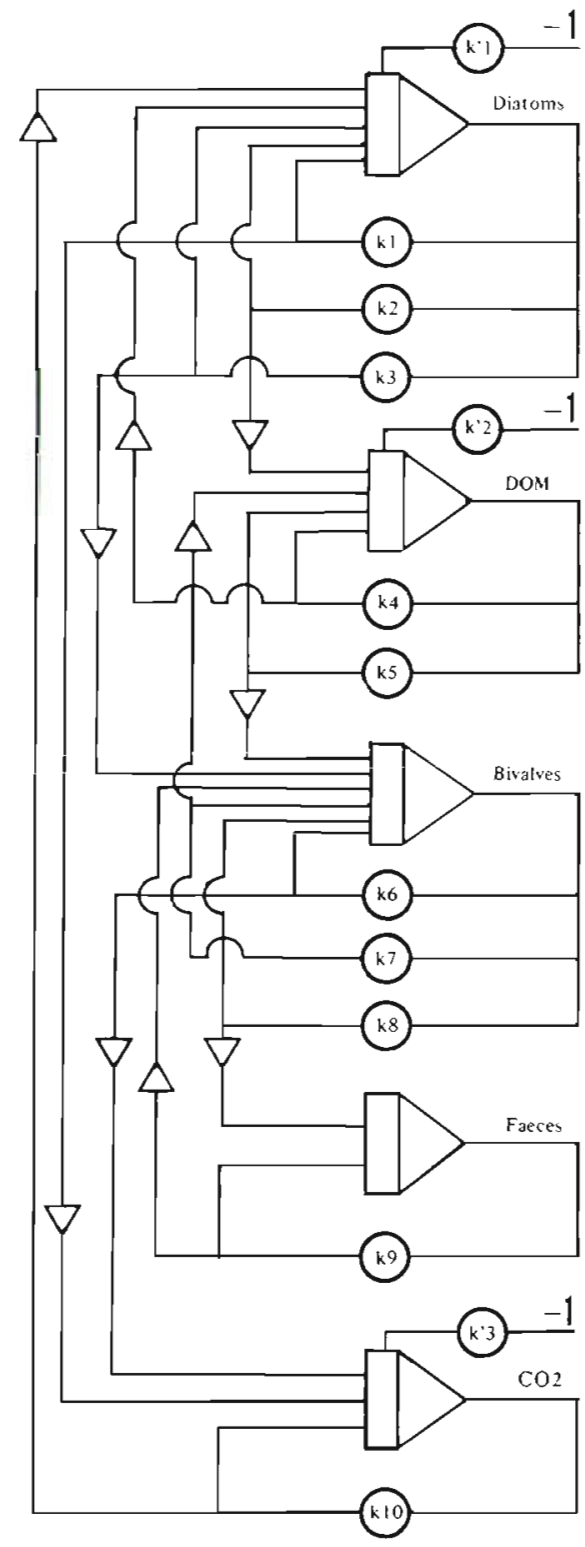

Fig. 3. Circuit diagram of computer and display constants after fitting of model 'Diatom-Seawater' system.

all cases the specific radioactivity of the cells declined over time. The radioactivity corresponding to $\mathrm{CO}_{2}$ and DOM increased rapidly during the first $10 \mathrm{~h}$. Then DOM decreased slightly as $\mathrm{CO}_{2}$ increased slowly (Table 2).

Consumption of DOM (filtrates) by the bivalves

After $4 \mathrm{~h}$, the percentages of radioactivity within the bivalves were: $1.1,2.9$ and $2.3 \%$ (means of 3 measurements) for Navicula incerta, Nitzschia acicularis and Nitzschia sp., respectively.
Table 1. Controls. Measurements of the concentration of the live diatoms in the flask over time. The low variations were induced by the ability of the diatoms to stick onto the walls of the flask. Values are expressed as $10^{7}$ cells $\mathrm{ml}^{-1}$

\begin{tabular}{|lcccc|}
\hline Diatom & $0 \mathrm{~h}$ & $4 \mathrm{~h}$ & $10 \mathrm{~h}$ & $48 \mathrm{~h}$ \\
\hline Navicula incerta & 13.1 & 2.8 & 13.3 & 12.5 \\
Nitzschia acicularis & 45.0 & 45.2 & 44.8 & 44.7 \\
Nitzschia sp. Roscoff & 61.0 & 61.2 & 60.8 & 60.7 \\
\hline
\end{tabular}

Consumption of live diatoms by the bivalves

The bivalves consumed the same quantities (about $50 \%$ after $48 \mathrm{~h}$ ) of Navicula incerta and Nitzschia acicularis (Table $3 \mathrm{~A}$ and $\mathrm{B}$ ). However $N$. acicularis was consumed faster than $N$. incerta during the first $4 \mathrm{~h}$. Radioactivity corresponding to DOM increased quickly during the first $4 \mathrm{~h}$ and then declined slightly. The bivalves quickly consumed Nitzschia sp. during the first $10 \mathrm{~h}$. Thereafter radioactivity in the bivalves remained constant (about $60 \%$ ). Radioactivity corresponding to particulate organic matter (diatoms + biodeposits) was low and constant (less than $10 \%$ ). Radioactivity corresponding to $\mathrm{CO}_{2}$ increased gradually to $25 \%$ (after $48 \mathrm{~h})$. Radioactivity corresponding to DOM reached $9.5 \%$ after $10 \mathrm{~h}$ and then declined to $4 \%$ after $48 \mathrm{~h}$.

\section{Modelling \\ Changes in viable diatoms alone over time}

During the first $3 \mathrm{~h}$ of the experiments, Navicula incerta was not consumed by Abra alba. The timeorigin of the model was shifted by $3 \mathrm{~h}$. At this time, radioactivity was distributed as follows: $87 \%$ in diatoms, $10 \%$ in DOM and $3 \%$ in $\mathrm{CO}_{2}$. The radioactivity declined regularly in the particulate (diatoms + faeces) from $87 \%(3 \mathrm{~h})$ to $50 \%(10 \mathrm{~h})$ and $8 \%$ (after $48 \mathrm{~h}$ ). $\mathrm{CO}_{2}$ rose from $5 \%$ after $4 \mathrm{~h}$ to $35 \%$ after $48 \mathrm{~h}$. DOM remained nearly constant (ca 10 to $11 \%$ ) throughout the experiment. The amount of faeces present on the bottom was low: $5 \%$ after 48 h. Radioactivity of diatoms decreased regularly to $3 \%$ after $48 \mathrm{~h}$. Radioactivity of diatoms decreased regularly to $3 \%$ after $48 \mathrm{~h}$. The production of faeces accumulated during 48 h was low: $19 \%$ (Figs. 7 and 8 ). For fitting the model, it was necessary to modify the values of the constant of integration (relative to those used for the model of the diatoms alone; Table 4). This implies that diatom metabolism $\left(\mathrm{CO}_{2}\right.$ and DOM exchanges) differed in the presence and absence of clams. Changes in the metabolism of $N$. incerta were revealed by changes in the values of these constants. The con- 


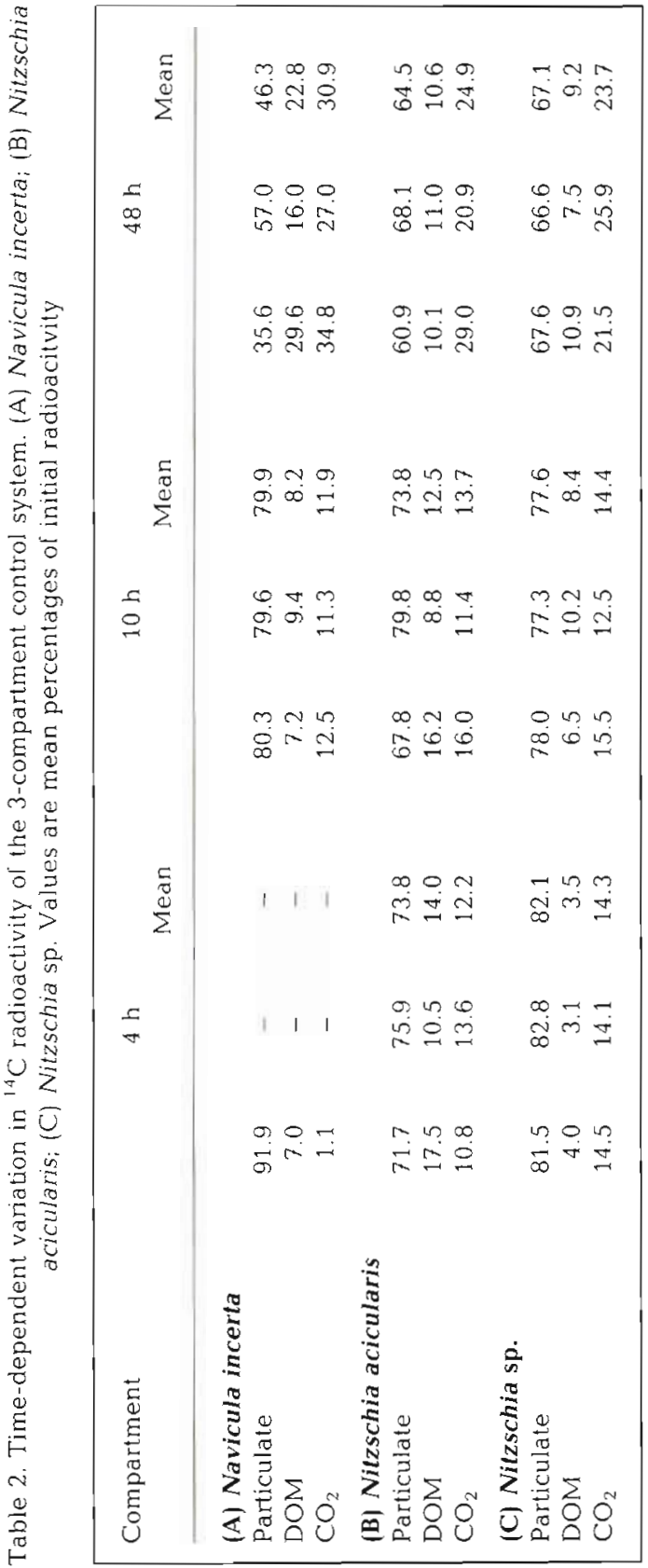

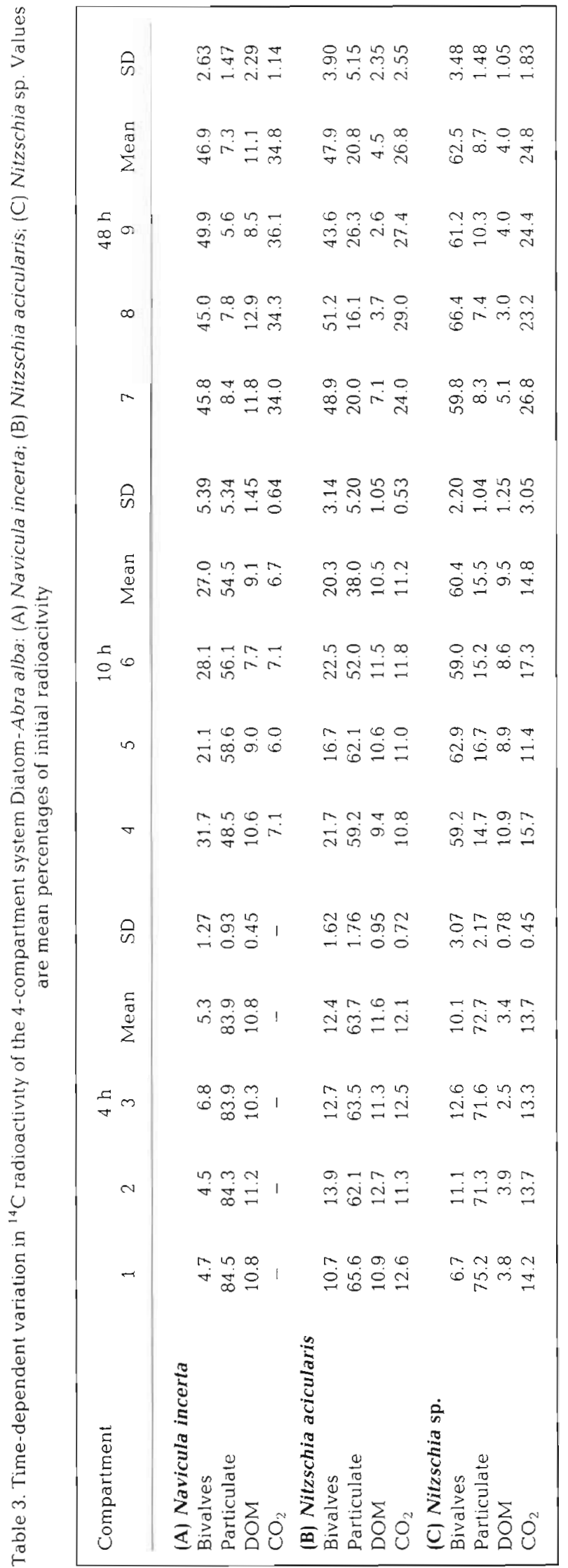


Table 4. Integration constants of the model Diatom-Seawater (controls). (A) Navicula incerta; (B) Nitzschia acicularis; (C) Nitzschia sp. $\mathrm{k} 4$ is the consumption of DOM by diatoms, $\mathrm{k} 2$ the production of $D O M, k 10$ the consumption of $\mathrm{CO}_{2}$ by the diatoms and $\mathrm{k} 1$ the production of $\mathrm{CO}_{2}$

\begin{tabular}{|cccc|}
\hline Constant & $\begin{array}{c}\text { Navicula } \\
\text { incerta }\end{array}$ & $\begin{array}{c}\text { Nitzschia } \\
\text { acicularis }\end{array}$ & Nitzschia sp. \\
\hline $\mathrm{k} 4$ & 0.0145 & 0.8001 & 0.2006 \\
$\mathrm{k} 2$ & 0.0135 & 0.1501 & 0.0328 \\
$\mathrm{k} 10$ & 0.0121 & 0.5309 & 0.3331 \\
$\mathrm{k} 1$ & 0.0436 & 0.1861 & 0.1001 \\
\hline
\end{tabular}

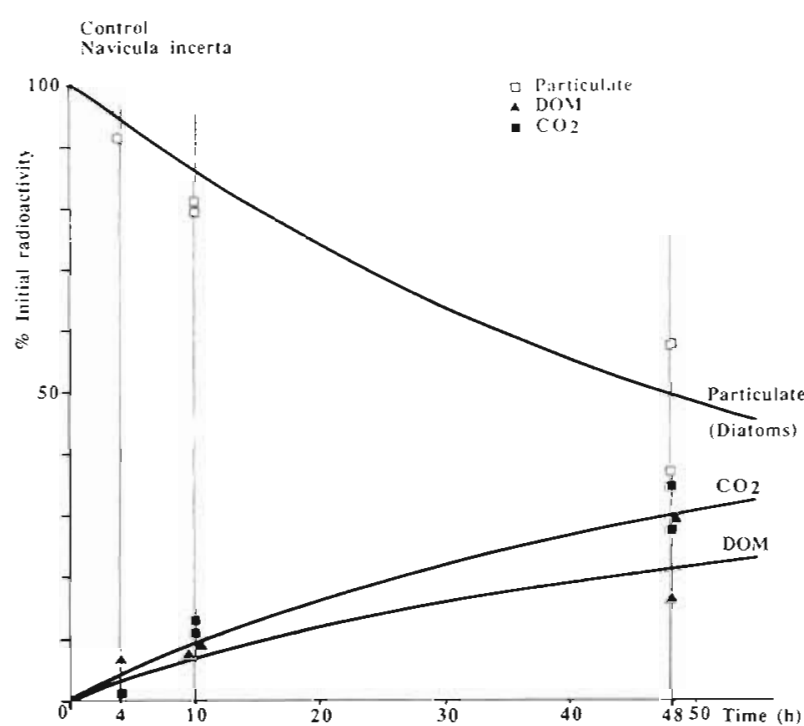

Fig. 4. Time-dependent variation in radioactivity of the different compartments of the control system Diatom-Seawater (Navicula incerta). Results are expressed as percentage of radioactivity introduced at start versus time elapsed $(\mathrm{h})$. Experimental data for the different experiments and compartments are pointed on the graph

stant $\mathrm{k} 2$ (DOM produced) changed from 0.0135 to 0.0201 ( 1.5 times more); $\mathrm{k} 4$ (DOM consumed) from 0.0145 to 0.0257 (2 times more); $\mathrm{k} 1 \quad\left(\mathrm{CO}_{2}\right.$ produced) from 0.0436 to 0.0810 (2 times more); and $\mathrm{k} 10\left(\mathrm{CO}_{2}\right.$ consumed) from 0.0120 to 0.0495 (4 times more) (Tables $5 \mathrm{~A}$ and 6$)$.

\section{Consumption of Nitzschia acicularis}

Nitzschia acicularis was initially consumed faster than Navicula incerta. Fitting the model revealed that actions of the bivalves altered the metabolism of the diatoms. Constants of integration were very different from those of the control (diatoms without bivalves). DOM production changed from 0.1500 to 0.0111 (13 times less); consumption of DOM from 0.8000 to 0.1200

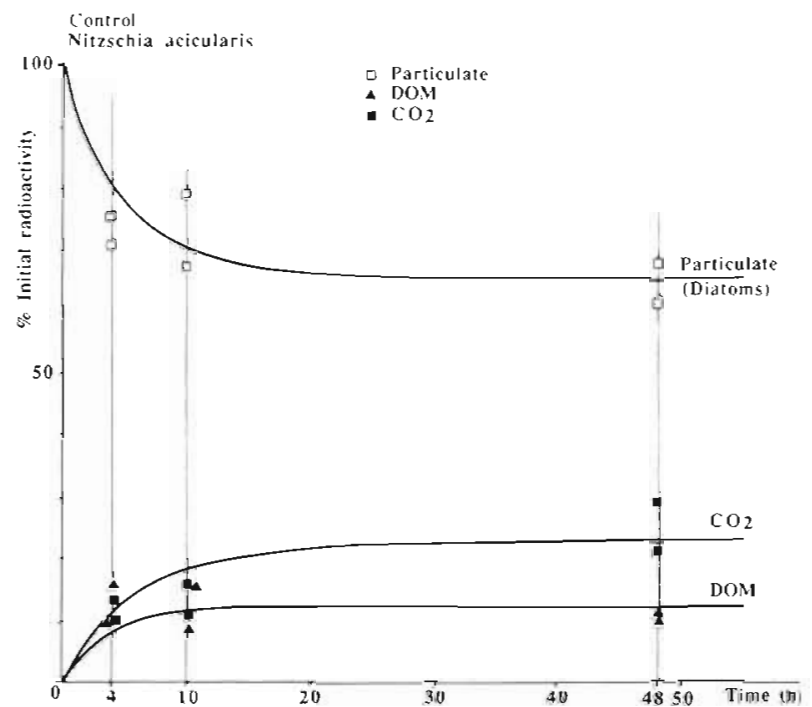

Fig. 5. Time-dependent variation in radioactivity ot the different compartments of the control system Diatom-Seawater (Nitzschia acicularis)

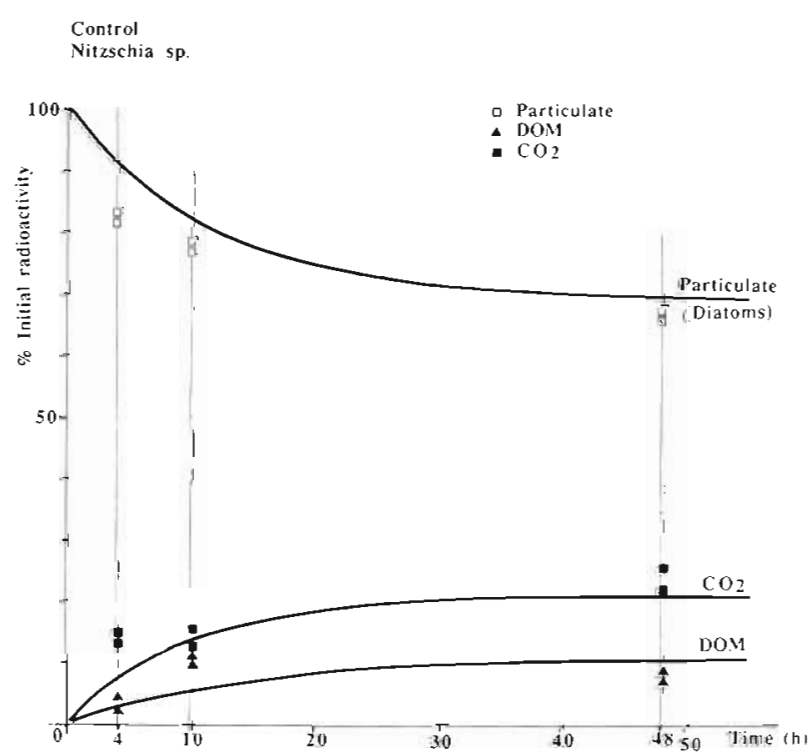

Fig. 6. Time-dependent variation in radioactivity of the differ ent compartments of the system Diatom-Seawater (Nitzschia sp.)

( 7 times less); production of $\mathrm{CO}_{2}$ from 0.1860 to 0.0108 (17 times less); consumption of $\mathrm{CO}_{2}$ from 0.5310 to 0.1306 (4 times less) (Tables 5B and 6). Radioactivity in the soft body of the bivalves increased gradually to $46 \%$ after $48 \mathrm{~h}$. During this time the radioactivity of the particulate declined gradually to $21 \%$ after $48 \mathrm{~h}$. Total $\mathrm{CO}_{2}$ rose from $13 \%$ after $10 \mathrm{~h}$ to $23 \%$ after $48 \mathrm{~h}$. DOM increased to $13 \%$ after $4 \mathrm{~h}$ and then declined to $11 \%$ after $10 \mathrm{~h}$, and to $4 \%$ after $48 \mathrm{~h}$; this indicates that DOM was reabsorbed first by diatoms and then by bivalves. Radioactivity of diatoms (as calculated by the 


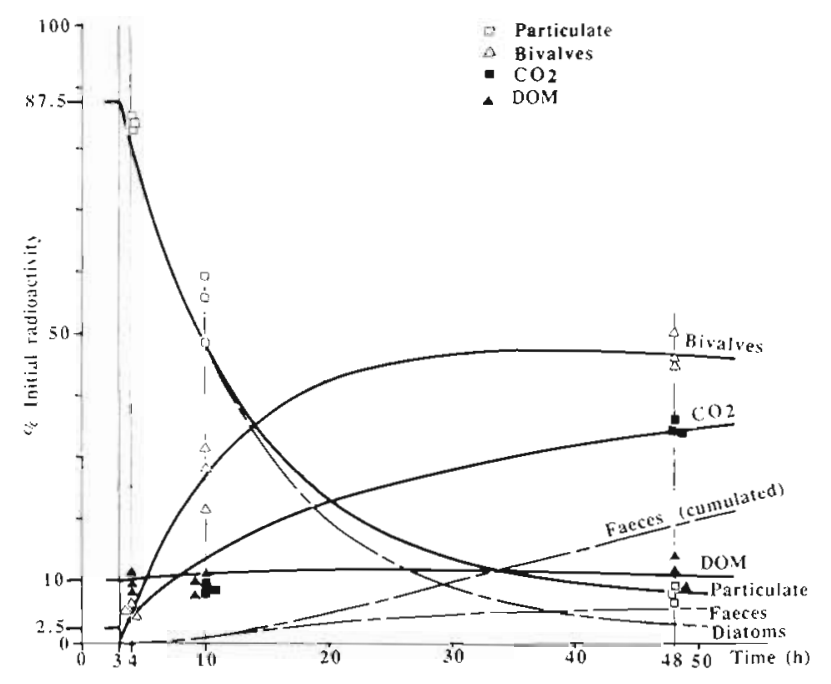

Fig. 7. Time-dependent variation in radioactivity of the different compartments of the system Diatom-Bivalve (Navicula incerta-Albra alba)

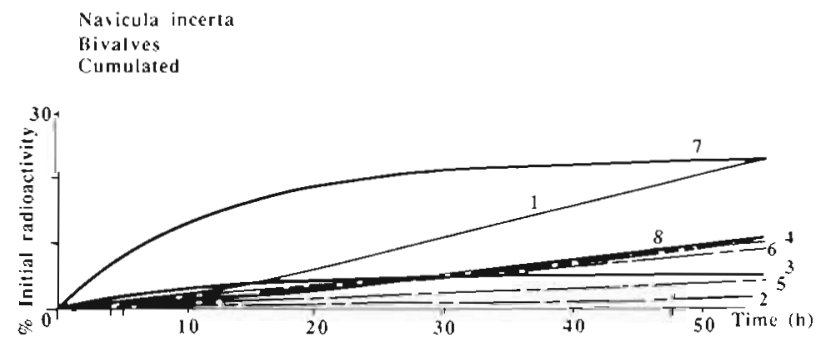

Fig. 8. Calculation of cumulated amounts of organic matter (radioactivity) transited through different compartments as a function of time during different exchanges. System DiatomBivalve (Navicula incerta-Abra alba). (1) Faeces; (2) $\mathrm{CO}_{2}$ consumed by diatoms; (3) DOM produced by diatoms; (4) DOM consumed by bivalves; (5) DOM consumed by diatoms; (6) DOM produced by bivalves; (7) $\mathrm{CO}_{2}$ produced by diatoms;

(8) $\mathrm{CO}_{2}$ produced by bivalves

model) declined steadily to $4 \%$ after 48 h. Radioactivity of faeces increased slowly to $17 \%$ after $48 \mathrm{~h}$. The amounts of radioactivity cumulated in the different compartments were low, except for the faeces: $50 \%$ after $48 \mathrm{~h}$ (Figs. 9 and 10; Tables 5B and 6).

\section{Consumption of Nitzschia sp.}

The consumption of Nitzschia sp. by Abra alba began $3 \mathrm{~h}$ after food introduction. At this time most of the radioactivity $(90 \%)$ corresponded to particulate matter (live diatoms), the remainder (10\%) was in $\mathrm{CO}_{2}$ (DOM: about zero). After $10 \mathrm{~h}$ ( $13 \mathrm{~h}$ of experimentation), only $10 \%$ of the diatoms were in particulate form. Radioactivity retained in the soft body of the bivalves was $60 \%$ after $13 \mathrm{~h}, 65 \%$ after $20 \mathrm{~h}$ and $62 \%$ after $48 \mathrm{~h}$. This implies that faeces were not abundant and
Table 5. Integration constants of the model Diatom-Abra alba (A) Navicula incerta, (B) Nitzschia acicularis, (C) Nitzschia sp. Time origin for fitting the model and initial conditions on the left; comparison with the integration constants of the control on the right. Values expressed as $\mathrm{h}^{-1}$

\begin{tabular}{|c|c|c|}
\hline Initial condition & Abra alba & Contral \\
\hline \multicolumn{3}{|c|}{ A. Navicula incerta } \\
\hline & $\mathrm{k} 1=0.0811$ & $\mathrm{k} 1=0.0436$ \\
\hline & $\mathrm{k} 2=0.0201$ & $\mathrm{k} 2=0.0135$ \\
\hline \multirow[t]{2}{*}{$\mathrm{T}_{0}=\mathrm{T}_{0}+3 \mathrm{~h}$} & $\mathrm{k} 3=0.0355$ & \\
\hline & $\mathrm{k} 4=0.0257$ & $\mathrm{k} 4=0.0145$ \\
\hline$k^{\prime} 1=0.875$ & $\mathrm{k} 5=0.0236$ & \\
\hline$k^{\prime} 2=0.100$ & $\mathrm{k} 6=0.0011$ & \\
\hline \multirow[t]{4}{*}{$\mathrm{k}^{\prime} 3=0.025$} & $\mathrm{k} 7=0.1106$ & \\
\hline & $\mathrm{k} 8=0.2848$ & \\
\hline & $\mathrm{k9}=0.4092$ & \\
\hline & $\mathrm{k} 10=0.0495$ & $\mathrm{k} 10=0.0121$ \\
\hline \multicolumn{3}{|c|}{ B. Nitzschia acicularis } \\
\hline & $\mathrm{k} 1=0.0108$ & $\mathrm{k} 1=0.1861$ \\
\hline & $\mathrm{k} 2=0.0111$ & $\mathrm{k} 2=0.1501$ \\
\hline \multirow[t]{2}{*}{$\mathrm{T}_{0}^{\prime}=\mathrm{T}_{0}$} & $\mathrm{k} 3=0.1509$ & \\
\hline & $k 4=0.1201$ & $\mathrm{k} 4=0.8001$ \\
\hline $\mathrm{k}^{\prime} 1=0.999$ & $\mathrm{k} 5=0.0108$ & \\
\hline $\mathrm{k}^{\prime} 2=0.000$ & $\mathrm{k} 6=0.0051$ & \\
\hline \multirow[t]{4}{*}{$\mathrm{k} \cdot 3=0.000$} & $\mathrm{k} 7=0.0946$ & \\
\hline & $\mathrm{k} 8=0.2007$ & \\
\hline & $\mathrm{k} 9=0.3114$ & \\
\hline & $\mathrm{k} 10=0.1306$ & $\mathrm{k} 10=0.5311$ \\
\hline \multicolumn{3}{|l|}{ C. Nitzschia sp. } \\
\hline & $\mathrm{k} 1=0.0941$ & $\mathrm{k} 1=01001$ \\
\hline & $\mathrm{k} 2=0.0052$ & $\mathrm{k} 2=0.0328$ \\
\hline \multirow[t]{2}{*}{$\mathrm{T}_{0}^{\prime}=\mathrm{T}_{0}+3 \mathrm{~h}$} & $\mathrm{k} 3=0.1023$ & \\
\hline & $\mathrm{k} 4=0.1431$ & $\mathrm{k} 4=0.2006$ \\
\hline $\mathrm{k}^{1} 1=0.900$ & $\mathrm{k} 5=0.0124$ & \\
\hline $\mathrm{k}^{2} 2=0.000$ & $\mathrm{k} 6=0.0011$ & \\
\hline \multirow[t]{4}{*}{$k \cdot 3=0.100$} & $\mathrm{k} 7=0.0751$ & \\
\hline & $\mathrm{k} 8=0.8992$ & \\
\hline & $\mathrm{k} 9=0.3064$ & \\
\hline & $\mathrm{k} 10=0.0361$ & $\mathrm{k} 10=0.3331$ \\
\hline
\end{tabular}

were quickly reconsumed by the bivalves. $\mathrm{CO}_{2}$ increased steadily from $10 \%$ after 3 h to $23 \%$ after $48 \mathrm{~h}$. DOM increased to $8 \%$ after $13 \mathrm{~h}$ and declined slightly to $4 \%$ after $48 \mathrm{~h}$. Calculations using the model show that faeces on the bottom were low (less than $7 \%$ ) and live diatoms less than $1 \%$ (Fig. 11). Calculation of the cumulated amount flowing through the different compartments shows that faeces produced during the whole experiment were less than $20 \%$ over 48 h (Figs. 11 and 12; Table 6). Diatom metabolism was modified by the activity of bivalves. Integration constants differed from those of diatoms in the absence of bivalves. $\mathrm{k} 2$ (production of DOM) changed from 0.0328 to 0.0052 ( 6 times less); $\mathrm{k} 4$ (consumption of DOM), from 0.2006 to 0.1431 (1.4 times less); $\mathrm{k} 1$ (production of $\mathrm{CO}_{2}$ ) remained fairly stable from 0.10000 to $0.0941 ; \mathrm{k} 10\left(\mathrm{CO}_{2}\right.$ consumed) changed from 0.3330 to 0.0361 ( 9 times less) (Tables 5C and 6). 
Table 6. Comparison of results after fitting the model. For each diatom species the amount of cumulated radioactivity is listed for each compartment after $50 \mathrm{~h}$. (1) Faeces; (2) $\mathrm{CO}_{2}$ consumed by diatoms; (3) DOM produced by diatoms; (4) D( $) 1$ consumed by bivalves; (5) DOM consumed by diatoms; (6) DOM produced by bivalves; (7) $\mathrm{CO}_{2}$ produced by diatoms; (8) $\mathrm{CO}_{2}$ produced by bivalves. Values expressed as percentages of initial radioactivity

\begin{tabular}{|c|c|c|c|}
\hline & $\begin{array}{c}\text { Navicula } \\
\text { incerta }\end{array}$ & $\begin{array}{l}\text { Nitzschia } \\
\text { acicularis }\end{array}$ & $\begin{array}{c}\text { Nitzschia } \\
\text { sp. }\end{array}$ \\
\hline (1) Faeces & 42.5 & 42.0 & 24.0 \\
\hline (2) $\mathrm{CO}_{2}$ cons. Diat. & 1.5 & 1.5 & 0.5 \\
\hline (3) DOM prod. Diat. & 5.0 & 34.0 & 12.0 \\
\hline (4) DOM cons. Biv. & 9.5 & 1.5 & 6.0 \\
\hline (5) DOM cons. Diat. & 4.0 & 23.0 & 6.5 \\
\hline (6) DOM prod. Biv. & 8.5 & 4.0 & 3.5 \\
\hline (7) $\mathrm{CO}_{2}$ prod. Diat. & 23.5 & 27.0 & 6.5 \\
\hline (8) $\mathrm{CO}_{2}$ prod. Biv. & 10.0 & 4.0 & 8.5 \\
\hline \multicolumn{4}{|l|}{$50 \mathrm{~h}$ present } \\
\hline Faeces & 5.5 & 17.5 & 7.0 \\
\hline Diatoms & 2.0 & 4.0 & 1.0 \\
\hline DOM & 10.5 & 4.0 & 0.4 \\
\hline Particulate & 8.0 & 21.0 & 7.5 \\
\hline Bivalves & 46.0 & 46.0 & 62.5 \\
\hline $\mathrm{CO}_{2}$ & 36.0 & 28.0 & 23.3 \\
\hline Amount consumed & 107.0 & 96.0 & 98.5 \\
\hline Amount ingested & 97.5 & 94.5 & 92.5 \\
\hline Faeces produced & 4.2 .5 & 42.0 & 24.0 \\
\hline Faeces recycled & 37.0 & 24.5 & 17.0 \\
\hline DOM consumed & 9.5 & 1.5 & 6.0 \\
\hline Amount assimilated & 54.5 & 54.0 & 74.5 \\
\hline
\end{tabular}

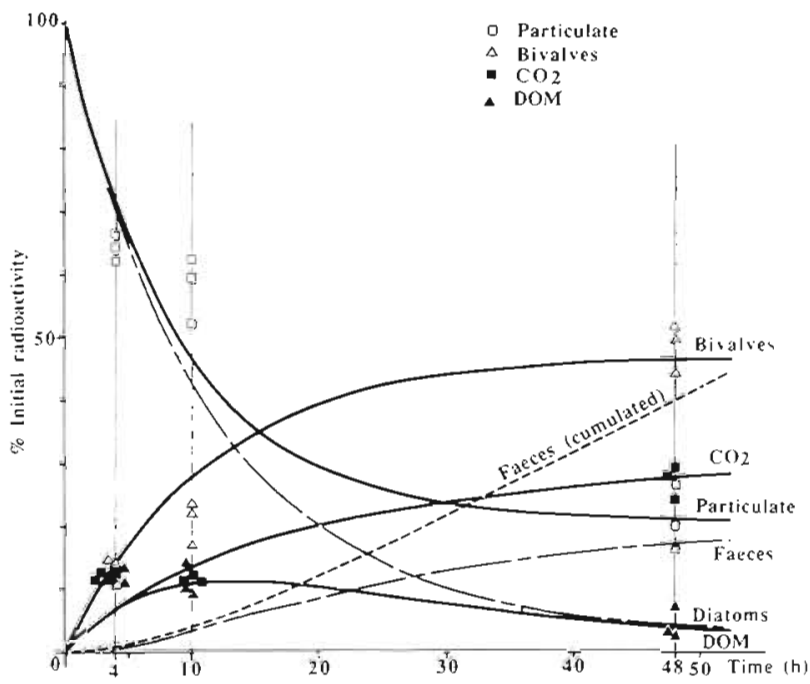

Fig. 9. Time-dependent variation in radioactivity of different compartments of the system Diatom-Bivalve (Nitzschia acicularis-Abra alba)

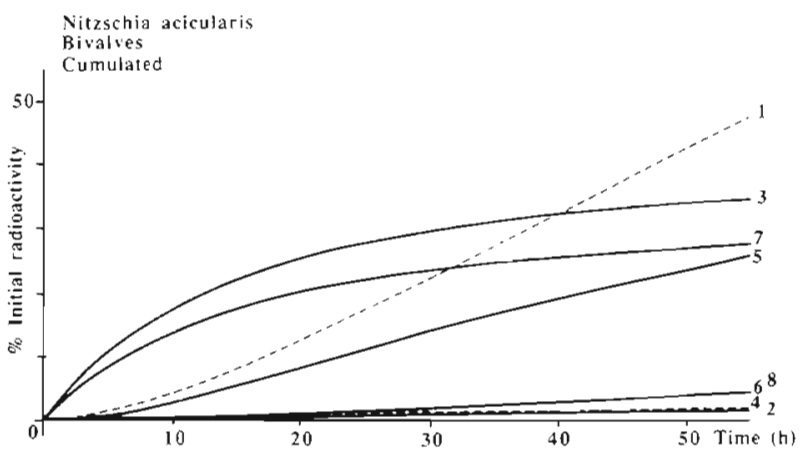

Fig. 10. Calculation of cumulated amounts of organic matter (radioactivity) transited through different compartments as a function of time during different exchanges. System DiatomBivalve (Nitzschia acicularis-Abra alba). (1) Faeces; (2) $\mathrm{CO}_{2}$ consumed by diatoms; (3) DOM produced by diatoms; (4) DOM consumed by bivalves; (5) DOM consumed by diatoms; (6) DOM produced by bivalves; (7) $\mathrm{CO}_{2}$ produced by diatoms; (8) $\mathrm{CO}_{2}$ produced by bivalves

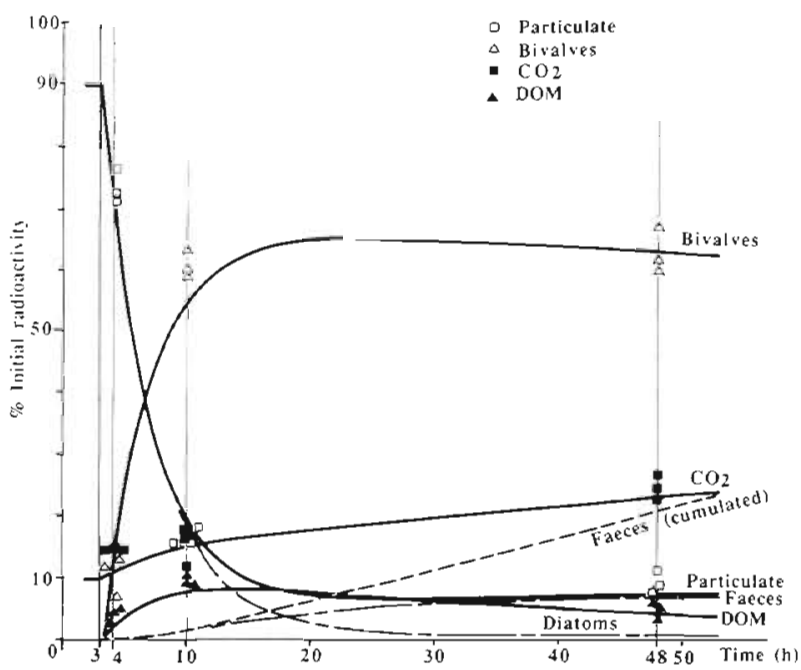

Fig. 11. Time-dependent variation in radioactivity of different compartments of system Diatom-Seawater (Nitzschia sp.)

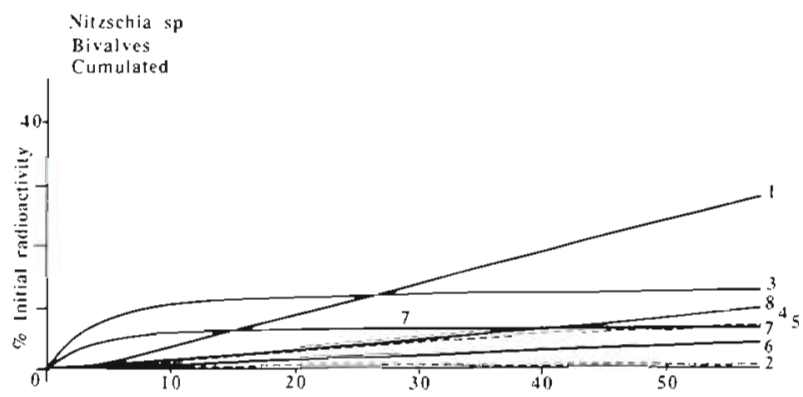

Fig. 12. Calculation of cumulated amounts of organic matter (radioactivity) transited through different compartments as a function of time during different exchanges. System DiatomBivalve (Nitzschia sp-Abra alba). (1) Faeces: (2) $\mathrm{CO}_{2}$ consumed by diatoms; (3) DOM produced by diatoms; (4) DOM consumed by bivalves; (5) DOM consumed by diatoms; (6) DOM produced by bivalves; (7) $\mathrm{CO}_{2}$ produced by diatoms; (8) $\mathrm{CO}_{2}$ produced by bivalves 


\section{Consumption, ingestion and assimilation}

Nitzschia sp. was most easily assimilated with $74.5 \%$ of initial radioactivity and $98.5 \%$ of food consumed and $92.5 \%$ ingested by the bivalves. Navicula incerta was more easily consumed, with $107 \%$ (values include recycled faeces) and $97.5 \%$ ingested and $54.5 \%$ assimilated, than $N$. acicularis, which was least assimilated with $54.0 \%$, and $96.0 \%$ consumed and $94.5 \%$ ingested (Table 6).

\section{DISCUSSION}

The purpose of the present study was to compare ingestion and assimilation of 3 different species of diatoms by the deposit-feeding bivalve Abra alba. Variation over time of controls reveals the loss in radioactivity of the 3 diatoms: Navicula incerta lost $200 \%$ more DOM (22.8\% after $48 \mathrm{~h})$ and $125 \%$ more of $\mathrm{CO}_{2}$ $(30.9 \%$ after $48 \mathrm{~h})$ than did Nitzschia acicularis and Nitzschia sp. Our study shows that it is possible to describe the exchanges of matter within the system using a compartmental (in contrast to an interface) model (Amouroux \& Amouroux 1988). This is probably due to the bioturbation by the bivalves which increases the homogeneity of the seawater near the bottom.

Abra alba ingests Nitzschia sp. rather than Navicula incerta or Nitzschia acicularis. The model permits the mathematical determination of the amounts of exudates and excretory products through POM and DOM and the amount produced or consumed by each compartment, even if these amounts are not experimentally measurable. Faeces (cumulated) produced by Abra alba were $42.5,42.0$ and $24.0 \%$ of the organic carbon introduced at the beginning of experiment for $N$. incerta, $N$. acicularis and Nitzschia sp., respectively. The amounts of assimilated matter were 54.5, 54.0 and $74.5 \%$, respectively.

These results can be compared with those of previous studies dealing with other deposit-feeders. Hargrave (1970a) reported $60 \%$ assimilated for the amphipod Hyatella azteca fed on diatoms, and $83 \%$ for $\mathrm{H}$. azteca fed on bacteria (experimental duration: 5 or $6 \mathrm{~h}$ ); Kofoed (1975) found 60 to $75 \%$ assimilated for Hydrobia ventrosa fed on Nitzschia angularis and other species of diatoms (the snails were in contact with their food for only $20 \mathrm{~min}$ ). However the balance of the total radioactivity introduced at the beginning of their experiments (Hargrave 1970a, Kofoed 1975) was not established and the excreted DOM seems to have been as low as 4 to $8 \%$ : a value that is equivalent to the data calculated by Nielsen \& Kofoed (1982) for the crustacean Corophium volutator (experimental duration: 20 min). Hargrave (1970a) reported $36 \%$ for $H$. azteca.
These animals feed differently: amphipods and gastropods browse over sediment particles and select them, while bivalves suck up the water containing fine particles and flocculates. The other workers' calculations did not consider the possibility of recycling of faeces by the animals. Further, experimental conditions were not the same: Hargrave used natural autoclaved sediment, Nielsen \& Kofoed used reconstituted sediment, and Kofoed used no sediment. It is not easy to use sediment as calculations are difficult and counting errors numerous. Diatom activity easily disturbs the balance by recycling of dissolved organic matter and $\mathrm{CO}_{2}$. However, in spite of such differences in experimental procedures, the calculated percentages of assimilated food are very similar.

To achieve a good fit of the model, some modifications in the integration constants corresponding to the metabolic exchanges of algae were required. This suggests that, while feeding, the bivalves affect the metabolic rates of diatoms. The metabolic rate of Navicula incerta was stimulated (its 4 constants of integration increased) whereas the metabolic rates of Nitzschia acicularis and Nitzschia sp. were inhibited (their 4 constants of integration declined). The constants decreased from 0.3330 to 0.0361 for $N$. incerta and from 0.8000 to 0.1200 for $N$. acicularis. This effect is similar to the inhibition of photosynthetic processes described by Sumner \& McIntyre (1982) on a system involving grazer-periphyton. The difference between Navicula incerta and the 2 other diatoms is presumably due to the adaptative differences in metabolic rate for the different species of diatoms (Gallagher et al. 1984, Mortain-Bertrand et al. 1988). Our experiments were carried out in darkness in order to limit the photosynthetic recycling of $\mathrm{CO}_{2}$ while permitting good activity by the bivalves. Unfortunately the dark metabolism of the different species of diatoms is not yet well known. Our results, too, cannot constitute additional physiological information. Hence the problem of valid reference data remains unsolved for experiments employing live foods. Bioturbation of diatoms induced by Abra alba caused a physiological response of diatoms similar to that reported for bacteria consumed by a predator (Sumner \& McIntyre 1982, Alongi 1985, Moriarty et al. 1985).

Deposit-feeders may consume organic matter from very different origins. Through bioturbation (Rhoads 1974, Aller \& Yingst 1985, Murphy 1985) they disaggregate the biodeposits, mix the interface watersediment, and recycle their own faeces (Newell 1965, Guidi \& Tito de Morais 1983). Such action stimulates bacterial growth (Branch \& Pringle 1987, Reichardt 1988 ) and dissolved excretion by microbes (Jensen 1983. Harvey \& Luoma 1984, Baird \& Thistle 1986). Deposit-feeders can also feed directly on diatoms or 
their dissolved exudates or colloids (Moriarty 1982. Connor 1986) or on bacteria (Hylleberg 1975, Dobbs \& Whitlach 1982, Reise 1983). Because of such complexity, a modelling approach is the only one that faciliates interpretation of experimental data on quantitative aspects of nutrition (ingestion, assimilation) in depositfeeders. More studies are necessary to determine the exact effects of deposit-feeding organisms on their food sources, and to quantify actual ingestion rates. The model that we have used in this study is probably imperfect; however, it provided an adequate description of our experimental data. Furthermore, it allowed (1) determination of the influence of the bivalves on the metabolic rate of the diatoms, and (2) quantification of the amounts of organic matter which passed through the bivalves (short-term energetic budget).

\section{LITERATURE CITED}

Admiraal, W., Peletier, H., Laane, R. W. P. M. (1986). Nitrogen metabolism of marine planktonic diatoms; excretion. assimilation and cellular pools of free amino acids in seven species with different cell size. J exp. mar. Biol. Ecol. 98: $241-263$

Aller, R. C., Yingst, J. Y (1985). Effects of the marine depositfeeders Heteromastus filiformis (Polychaeta), Macoma balthica (Bivalvia), and Tellina texana (Bivalvia) on averaged sedimentary solute transport, reaction rate, and micorbial distributions. J. mar. Res. 43: 615-645

Alongi, D. M. (1985). Microbes, meiofauna, and bacterial productivity on tubes constructed by the polychaete Capitella capitata. Mar. Ecol. Pro. Ser 23ß 207-208

Amouroux, J. M. (1984). Preliminary study on the consumption of dissolved organic matter (exudates) of bacteria and phytoplankton by the marine bivalve Venus verrucosa. Mar. Biol. 82: 109-112

Amouroux, J. M. (1986a). Comparative study of the carbon cycle in Venus verrucosa fed on bacteria and phytoplankton. I. Consumption of bacteria (Lactobacillus sp.). Mar Biol. 90: 237-241

Amouroux, J. M. (1986b). Comparative study of the carbon cycle in Venus verrucosa fed on bacteria and phytoplankton. II. Consumption of phytoplankton (Pavlova lutheri). Mar. Biol. 92: 349-354

Amouroux, J. M., Amouroux, J. (1988). Comparative study of the carbon cycle in Venus verrucosa fed on bacteria and phytoplankton. III. Comparison of models. Mar Biol. 97: 339-347

Baird, B. H., Thistle, D. (1986). Uptake of bacterial extracellular polymer by a deposit-feeding holothurian (Isostichopus badionotus). Mar. Biol. 92: 183-187

Branch, G. M., Pringle, A. (1987). The impact of the sand prawn Callianassa kraussi Stebbing on sediment turnover and on bacteria, meiofauna, and benthic microflora. J. exp. mar Biol. Ecol. 107: 219-235

Briggs, K. B. (1985). Deposit feeding by some deep-sea megabenthos from the Venezuela Basin: selctive or nonselective. Mar. Ecol. Prog. Ser 21. 127-134

Connor, V M. (1986). The use of mucous trails by intertidal limpets to enhance food resources. Biol. Bull. mar. biol. Lab., Woods Hole 171 548-564

Dring, M. J., Jewson, D. H. (1982). What does ${ }^{14} \mathrm{C}$ uptake by phytoplankton really measure? A theoretical approach. Proc. R. Soc. B 214: 351-368

Dobbs, F. C., Whitlach, R. B. (1982). Aspects of depositfeeding by the polychaete Clymenella torquata. Ophelia 21: $159-166$

Fenchel, T (1970). Studies on the decomposition of organic detritus derived from the turtle grass Thalassia testudinum. Limnol. Oceanogr. 15: 14-20

Fenchel, T. (1972). Aspects of decomposer food chains in marine benthos. Verh. dt. zool. Ges. 65: 14-22

Fogg. G. E. (1966). The extracellular products of algae. Oceanogr mar Biol. A. Rev. 4: 195-212

Gallagher, J. C., Wood, A. M., Alberte, R. S. (1984). Ecotypic differentiation in the marine diatom Skeletonema costatum: influence of light intensity on the photosynthetic appararus. Mar. Biol. 82: 121-134

Goldstein, R. A., Elwood, J. W. (1971). A two compartment, three parameter model for the absorption and retention of ingested element by animals. Ecology 52 (5): 935-939

Grégoire, F. (1972). Pharmacocinétique et analyse compartimentale. J. Pharm. Belg. 27 (1): 98-111

Guidi, L. D., Tito de Morais, A. (1983). Ascidian faecal pellets and their utilization by an epibenthic amphipod. J. exp. mar. Biol. Ecol. 71: 289-298

Guilliard, R. R. L., Ryther, J. H. (1962). Studies on marne planktonic diatoms. I. Cyclotella nana Hustedt and Detonula confervacea (Cleve) Gran. Can. J. Microbiol. 8: 229-239

Hargrave, B. T. (1970a). The utilization of benthic microflora by Hyatella azteca (Amphipoda). J. Anim. Ecol. 39: 427-437

Hargrave, B. T (1970b). The effect of a deposit-feeding amphipod on the metabolism of benthic microflora. Limnol. Oceanogr 15: 21-30

Harvey, R. W., Luoma, S. N. (1984). The role of bacterial exopolymer and suspended bacteria in the nutrition of the deposit-feeding clam, Macoma balthica. J. mar. Res. 42: 957-968

Hyl..eberg, J. (1975). Selective feeding by Arenicola pacifica with notes on Abarenicola vagabunda and a concept of gardening in lugworms. Ophelia 14: 113-13?

Hylleberg, J., Galucci, V (1975). Selectivity in feeding by the deposit feeding bivalve Macoma nasuta. Mar. Biol. 32: $167-178$

Jensen, L. M. (1983). Phytoplankton release of extracelluar organic carbon, molecular weight composition, and bacterial assimilation. Mar. Ecol. Prog. Ser 11: 39-48

Kemp, P. F. (1987). Potential impact on bacteria grazing by a macrofaunal deposit-feeder, and the fate of bacterial production. Mar. Ecol. Prog. Ser. 36: 151-161

Kofoed, L. H. (1975). The feeding biology of Hydrobia ventrosa (Montagu). I. The assimilation of different components of the food. J. exp. mar Biol. Ecol. 19: 233-241

Lopez, G. R, Levinton, J. S., Slobodkin, L. B. (1977). The effect of grazing by the detritivore Orchestia grillus on Spartina litter and its associated microbial community. Oecologia (Berl.) 30: 111-127

Mague, T H., Friberg, E., Hughes, J. D., Morris, I. (1980). Extracellular release of carbon by marine phytoplankton: a physiological approach. Limnol. Oceanogr. 25: 262-270

Moriarty, D. J. W. (1982). Feeding of holothurians on bacteria and organic matter. Aust. J. mar. Freshwat. Res. 33: 255-263

Moriarty, D. J. W., Pollard, P. C., Hunt, W. G., Moriarty, C. M., Wassenberg, I J. (1985). Productivity of bacteria and microalgae and the effect of grazing by holothurians in sediments on a coral reef flat. Mar Biol. 85: 292-300

Mortain-Bertrand, A. (1987). Influence des fluctuations lumineuses sur le métabolisme photosynthétique et la pro- 
ductivité de diatomées tempérées et antartiques en cultures. These Doct. Univ. Paris 6. Sciences de la vie Algologie

Mortain-Bertrand, A., Descolas-Gros, C., Jupin, H. (1988) Pathway of dark inorganic carbon fixation in two species of diatoms: influence of light regime and regulator factors on diel variations. J. Plankton Res. 10: 199-227

Murphy, R. C. (1985). Factors affecting the distribution of the introduced bivalve Mercenaria mercenaria, in a California lagoon. The importance of bioturbation. J. mar Res. 43 673-692

Newell, R. (1965). The role of detritus in the nutrition of two marine deposit feeders, the prosobranch Hydrobia ulvae and the bivalve Macoma balthica. Proc. zool. Soc. Lond. 144: $25-45$

Nielsen, M. V., Kofoed, L. H. (1982). Selective feeding and epipsammic browsing by the deposit-feeding amphipod Corophium volutator. Mar. Ecol. Prog. Ser 10:81-88

Odum, W E. (1968). The ecological significance of fine particle selection by the striped mullet Mugil cephalus. Limnol. Oceanogr 13: 92-98
Petch, D. A. (1986). Selective deposit-feeding by Lumbrineris latreilli (Polychaeta: Lumbrineridae), with a new method for assessing selectivity by deposit-feeding organisms. Mar Biol 93: 443-448

Reichardt, W (1988). Impact of bioturbation by Arenicola marina on microbiological parameters in intertidal sediments. Mar. Ecol. Prog. Ser 44: 149-158

Reise, K. (1983). Biotic enrichment of intertidal sediments by experimental aggregates of the deposit-feeding bivalve Macoma balthica. Mar. Ecol. Prog. Ser 12: 229-236

Rhoads, D. C. (1974). Organism-sediment relations on the muddy sea floor Oceanogr. mar Biol. A. Rev. 12: 263-300

Smith, D. F., Horner, S. M. J. (1981). Tracer kinetic analysis applied to problems in marine biology. Can Bull. Fish. Aquat. Sci. 210: 113-128

Sumner, W T., McIntyre, C. D. (1982). Grazer-periphiton interactions in laboratory streams. Arch. Hydrobiol. 93 (2): 135-157

Whitlach, R. B., Weinberg, J. R. (1982). Factors influencing particle selection and feeding rate in the polychaete Cistenides (Pectinaria) gouldii. Mar Biol. 71. 33-40

This article was submitted to the editor; it was accepted for printing on October 14, 1988 